\title{
THE NEW METHODOLOGY OF NEGOTIATING WITH THE CANDIDATE COUNTRIES IN THE CONTEXT OF MACRON'S RESHAPING OF EUROPEAN UNION
}

\author{
Bojana Lalatović, LLM, PhD candidate \\ Faculty of Law, University of Belgrade \\ Bulevar kralja Aleksandra 67, Belgrade 11000 \\ bojana.lalatovic@rycowb.org
}

\begin{abstract}
The enlargement policy of the European Union is known to be one of its best policies, as it has united a continent, stretched the single market and the common policies, thus conforming many aspects of economic and social life in the European countries. The Western Balkan has become, since the dissolution of ex-Yugoslavia, a very important geopolitical region, known also to be the soft belly of Europe. Thessaloniki Summit, held back in 2003, stamped the European perspective on the Western Balkans and declared it as a near future for the region. Since the entering of Romania and Bulgaria in 2007, it has tightened the negotiation rules, pointing out that the Rule of Law is the most important principle and measure of success for the candidate countries. Now, almost seventeen years from the Thessaloniki moment, the EU has stopped the enlargement policy, as the Member States have not found common ground as to open negotiation talks with North Macedonia and Albania. It seems fair to say that the enlargement does not have anymore its geopolitical relevance. It seems that the EU, due to the financial crisis in 2008, and then the migration crisis that followed, has lost its capacity to absorb new member states. However, France, which is starting to play a more central role in the European centerfield, is proposing a new approach to the Western Balkans, presenting a new methodology. The main point of the French proposal is to gradually include candidate countries in the club, by making them achieve certain rights by passing through various phases, seven of them exactly. One of the most important aspects is also the fact that the candidate countries would have access to structural funds, which they do not have today. However, the French proposal isn't peacefully accepted yet, as many countries have objected. From a geopolitical standpoint, how is this affecting Europe and how the Western Balkan region? Are Macron's proposals going to slow down the reform processes, thus endangering all that has been accomplished so far? In terms of common foreign and security policy, and the external action of the EU, can the new methodology play a role? In the context where the EU has to play a more active role in the neighbouring regions, it needs stability and more strength. Will Macron deliver just what is needed or will he turn the situation upside down?
\end{abstract}


Analytical and comparative methods will be dominantly relied upon throughout the paper allowing the author i.e. to draw the arguments supporting or challenging the above mentioned dilemmas and issues raised.

Keywords: European integration, Rule of law, Negotiation methodology, French Non paper

\section{INTRODUCTION}

The enlargement policy has been regarded as one of the most successful EU foreign policy instruments, since the establishment of the European Coal and Steel Community (ECSC) by the Treaty of Paris in 1951. Six waves of enlargement rounds have increased the number of Member States from the initial six founders ${ }^{1}$ to its current number of 27 countries. $^{2}$

Besides geopolitical terms and popular narratives used to define the Western Balkans, that range from "dysfunctional institutional structures", "captured states", "hybrid regimes - falling in the wide spectrum between consolidated democracies and autocracies", to "competitive authoritarian systems", ${ }^{3}$ the past two decades have been marked by strong and almost unequivocal advancement of these countries towards the EU. Meanwhile, the sole EU has been perceived as a panacea for the aforementioned disorders and problems respective countries were facing.

Despite the Thessaloniki promice, the Western Balkan States are still in the waiting room for accession to the EU, while Brussels is expecting substantial reforms and will accept only those countries that fulfil criteria of a fully democratic and liberty oriented system. However, there are certain aspects that have to be taken into consideration: the statecrafting happened since the dissolution of Yugoslavia and the time usually needed for new and young democracies to evolve. The process of European integration has already shown that it can be a fasting track towards the implementation of core principles upon which Democracy is built. The question arises whether the Rule of Law will prevail or the law of power in a delicate structure of young democracies, and what is the role of the EU.

The sort of metamorphosis, which a candidate state is supposed to go through, at the later stages should result in significant improvement of capacities of the respec-

These countries are Belgium, France, Italy, Luxembourg, the Netherlands, and West Germany

2 The current population of Europe is 747,479,037 as of Monday, February 24, 2020; Europe's population is equivalent to $9.78 \%$ of the total world population, [https://www.worldometers.info/world-population/europe-population/], accessed on 24. February 2020

3 Levitsky, Steven; Way, A. Lucan, Competitive authoritarianism, Hybrid regimes after the cold war, Cambridge University Press, Cambridge, 2010, p. 365-371; Keil, Soeren, The Business of State Capture and the Rise of Authoritarianism in Kosovo, Macedonia, Montenegro and Serbia, Southeastern Europe vol. 42, no. 1,2018 , p. 59-82 
tive state to "shoulder the burden" which the EU membership inevitably imposes. In other words, becoming a fully-fledged Member State, means that a state should be capable of coping up with the competitive pressure at the EU market, act in a spirit of solidarity, develop functioning rule of law - being among the core principles and values upon which the Union is based.

Yet, progressing on the path towards joining the EU, shouldn't be regarded only as an important step for a certain aspiring state in its relations with the EU, but also as a clear testimony of the EU's strength reflected in a continued commitment to the so-called European perspective of the Western Balkans. Nevertheless, developments within the EU and recent turmoil between the Member States, have provided a strong impetus for a deeper question of whether the EU delivers on its commitments, once a state pretending to become an EU candidate had met the conditions set out by the stakeholder, and whether the bumpy road of EU accession negotiations is rewarding to the extent as it has been previously thought?

The main motive fuelling this sort of discussions or "the straw that broke the camel's back" was famous French "non" to opening negotiation talks with North Macedonia and Albania, which paradoxically came after many assurances made by the EU leaders towards these countries - that precisely in light of these promises did some historical shifts, as it was signing of the Prespa agreement in case of North Macedonia. ${ }^{4}$ This outcome suggesting that the Thessaloniki promise of future EU membership of the region in light of such moves, is fading into oblivion, provoked turmoil among EU member states.

Therefore, the explained recent scenario leads us to one of the core arguments of this study, which is that the mentioned overturn seriously questions the negotiation process itself. At the same time, it is posing a dilemma over whether it is justified to refer to it as a "merit based process", in which the pace of progress of an individual state primarily depends on its own ability to meet the requirements for membership.

Given the European destiny of the Western Balkans, the accession procedure gains much importance. While the candidate countries have to transform themselves, the accession process says a lot about the EU's consistency and the role some member states play. Geopolitics is a major factor that has influenced and still influences this process. It can shape many "historic moments" that can impact the transformation of candidate countries and question arises if it is the process itself

North Macedonia signed the historical Prespa Agreement with Greece, and accepted the compromise solution to the decades-long dispute about its own name 
that should be immune to that context changing. Isn't that the definition of coherence, but in this case the EU's one?

This brings us to the actual moment. As this article will try to highlight, Macron wants to put the accession talks out of the technocratic process, but he wants the Member States more involved politically. Analysing this impetus aimed at changing what has been believed to be just a procedure, this article will try to tackle the necessary role accession talks have and should have in the context of an evolving European Union and the world. What will be the starting assessment is that the accession talks are not a mere bureaucratic process, and that on the other hand, a sharper political involvement of the Member States could put the same process of Enlargement at the mercy of their internal political life. While the first would be beneficial for the Rule of law and democracy, the second aspect would mean itself a constant threat to the continuity of the process.

This paper assesses recent French and EU moves in order to make sense of the overall direction of the European enlargement policy and its wider impact on the current and future relationship between the European Union and the Western Balkans. First, it presents the rules and principles governing the negotiation processes, while it also describes its substance that is mirrored in a mixture of complex legal and (geo)political structures and trends shaping the overall process. Further, it discusses French Non paper and EU New negotiation methodology that are in a way rejecting entrenched "status quo" and "stabilitocracies" throughout the region by advocating for more substantial reforms in the area of fundamentals, e.g. rule of law, able to provide a breath of fresh air into EU enlargement policy. Therefore, this study closely scrutinizes the dynamics present in both the EU and WB in terms of trends, patterns and paradoxes beyond the procedural nexus of rules and principles governing the overall process leading to EU expansion. In conclusion, it reiterates main assessments that at the same time could be regarded as recommendations to Europe to help advance its policies towards its nearest neighbours.

In methodological terms, this article has emerged as a product of holistic approach, and use of various methods of scientific research. Legal, comparative, analytical methods have been widely relied upon for the sake of drawing some major conclusions of this article, as well as parallels between different approaches towards countries aspiring to membership. An important aspect of the comparative method used in this article is also reflected in the confrontation of ideas and proclaimed values with their actual outreach in the empirical sense. The methods used allowed for making conclusions about the potential directions in which EU enlargement policy could move - driven by two sorts of forces, namely the inwardoriented policies of certain members, or by community sentiments upholding the 
basic values at the heart of the EU project. This approach also allowed for deduction of factors able to contribute to improvements in the overall strategy and vision of the Enlargement policy - that has largely been regarded as the sharpest tool of the EU foreign policy so far.

\section{NEGOTIATION FRAMEWORK AND CORE NEGOTIATION PRINCIPLES}

The accession process is much more than a bureaucratic procedure. It represents a stage where third states integrate with the family of EU member countries and become a part of a united community. Candidate countries are assessed in terms of their capacity to handle the membership, economically and politically. Therefore, the accession methodology should respect certain ground rules: namely, it should assess each country individually, in order to be really merit-based; it should respect each country's path and make it independent to foreign incognitas, such as political turmoils and changing of positions by individual member states, which could break the process or slow it down; it should gradually include them into the EU's framework, enabling them to develop their economy and political systems, to reach the level needed for the membership; it should, ultimately, treat the candidate countries as members of the same civilizational circle, same polity, even before their formal membership, which means first of all that the accession methodology has to defend EU's geopolitical influence over the candidate countries. This thesis can be synthesized in four principles: continuity, graduality, individuality and political unity. Based on these principles this article will tackle the proposals for new accession methodologies made by France and later on by the EU.

Ernst Haas, one of the leading theorists in this field, defined European integration as "a process whereby political actors in several distinct national settings are persuaded to shift their loyalties, expectations and political activities toward a new centre, whose institutions possess or demand jurisdiction over pre-existing national states". ${ }^{5}$ The overall process of European integration is being referred to as the 'Europeanization'6 and it has been among the major challenges in the last thirteen years for the rapidly transforming legal systems of Western Balkan postcommunist nations. This period could be also depicted as part of a broader postcommunist legal crisis marked by "incompetent drafting of post-communist law, the immaturity of post-communist legal systems and judges adhering to textual

Haas, B. E., The Uniting of Europe, Stanford University Press, Stanford, 1958, p. 139-140

Eriksen, M., Europeanization of the Balkans within an Identity-based Framework, Politeja, no. 37, 2015, p. $193-208$ 
positivism". ${ }^{7}$ Although Western Balkan countries were facing different challenges during the mentioned period, they have also seen important legislative developments in various spheres that the EU acquis embraces and, therefore, regulates.

Before analysing the proposals for a new accession methodology and the state of play, it is necessary to recall the norms that regulate this process. The key principles that provide for a legal basis of the EU accession negotiation process are stipulated by Article 49 of the Treaty on European Union (hereinafter TEU), as well as by other relevant conclusions brought by the European Council, such as the conclusions of the 1993 European Council in Copenhagen. ${ }^{8}$

The essential prerequisites that an aspiring member state needs to satisfy in order to pass the first stage and acquire a candidate status are twofold. Firstly, it needs to respect and to be committed to promoting values, upon which the sole EU has been founded. These essential values are stipulated by the Article 2 of the TEU, namely respect for human rights, pluralism, tolerance, human dignity, freedom, democracy, equality, as well as the pervasive principle of the rule of law. ${ }^{9}$ Secondly, certain degree of compliance with the membership criteria needs to be achieved, among which are the political criteria, laid out the Copenhagen and Madrid European Councils formulated in 1993 and 1995, respectively, as well as with the criteria introduced by the Council in 1997 within the Stabilization and Association process. ${ }^{10}$

The Copenhagen criteria laid down more precise political, economic, judicial and administrative conditions an applicant states needs to fulfil before it can enter the Union, such as: the stability of institutions guaranteeing democracy, human rights, functioning market economy, etc.

$7 \quad$ Kühn, Z., The Application of European Law in the New Member States: Several (Early) Predictions, German Law Journal, vol. 6, no. 3, 2005, p. 563-582., [doi:10.1017/S207183220001381X], accessed on 02. March 2020

8 Treaty on functioning of the European Union (Consolidated version 2016) Art. 49, [2016] OJ C 202/43 [https://eur-lex.europa.eu/legal-content/EN/TXT/?uri=CELEX\%3A12016M049], accessed on 23. February 2020

9 Appicciafuoco, L., The Promotion of the Rule of Law in the Western Balkans: The European Union's Role, German Law Journal, vol. 11, no. 7-8, 2010, p. 761, [doi:10.1017/S2071832200018824], accessed on 20. March 2020

10 As part of the Federal Republic of Yugoslavia, Montenegro and Serbia became participants in the Stabilization and Association process in November 2000, North Macedonia (the Former Yugoslav Republic of Macedonia) became part of the process in March 2004, Bosnia and Macedonia in July 2008, Albania in April 2009, Kosovo in November 2015 
Furthermore, the common framework for relations with all Western Balkans countries until the date of their accession, called Stabilization and Association process ${ }^{11}$ primarily focuses on development of closer regional ties established through good neighbourly cooperation. Although "good neighbourliness" 12 has been part of the enlargement conditionality since the beginning, in the case of the Western Balkan it became even more explicit and much more emphasised as a precondition of future enlargements. In the Communication on EU Enlargement Policy released in the first half of 2019, the European Commission made unequivocally clear its view that: "the EU cannot and will not import bilateral disputes and the instability they can entail". ${ }^{13}$ For instance, in the case of Serbia these prerequisites are embodied in the so-called "visible and sustainable improvement/normalization in relations with Kosovo*". ${ }^{14}$

Overall, in addition to legislative alignment, the candidate states need to be capable of timely and effective implementation of the Acquis communautaire, which is constantly evolving. The Union Acquis encompasses various principles, values, political objectives stipulated by the Founding Treaties, case law of the Court of Justice of the EU, inter-institutional agreements, resolutions, guidelines, international agreements concluded by the EU, etc. Although "theoretical part" of the legislative alignment did not turn out to be problematic for the Western Balkan countries, they were struggling with implementation related issues - which roots are inevitably leading to the structural problems in functioning of Balkan "democracies" which are lacking a well-functioning and stable public administration, ${ }^{15}$ independent and efficient judicial system. Moreover, the conditionality of the negotiating process puts the candidate countries in a position where they have to implement new legal norms created by the EU and are "binded" by them but

11 Triantaphyllou, D. et al., The Balkans between Stabilisation and Membership, in Partners and Neighbours: a CFSP for a Wider Europe, European Union Institute for Security Studies (EUISS), 2003, p. 69-71

12 Sjursen,H.; Smith, E. K., Justifying EU Foreign Policy, the logics underpinning enlargement, in: Tonra, B.;, Christiansen, T., (eds.), Rethinking European Union Foreign Policy (Europe in Change), Manchester University Press, Manchester, 2004, p. 134

13 European Commission, Communication from the Commission to the European Parliament, the Council, the European Economic and Social Committee and the Committee of the Regions, 2019 Communication on EU Enlargement Policy, Brussels, OJ, 29 May 2019, 2019/260/EC

14 Commission Staff Working Document Serbia 2019, Report Accompanying the document Communication from the Commission to the European Parliament, the Council, the European Economic and Social Committee and the Committee of the Regions 2019 Communication on EU Enlargement Policy, OJ, 29 May 2019, 2019/260/EC

15 Cardona, F., Integrating national administrations into the European administrative space, SIGMA Conference on Public Administration Reform and European Integration, March 2009, p. 26-27 [http:// www.sigmaweb.org/publicationsdocuments/42747690.pdf], accessed on 23. February 2020 
have no access to instruments and foras reserved for member states. Therefore, the proposal of gradually involving candidate countries in the EU's framework is much needed and would transform the negotiating process into a durable process of integration.

\subsection{Time as an actor of the negotiation process}

The European integration of Western Balkan states represents a parallel structural process to the one of state-crafting that has been happening since the 1990s. Indeed, Montenegro and Kosovo are the newest democracies in Europe, meanwhile, Bosnia and Herzegovina, Serbia, are countries that are still building up their institutions. The creation of solid institutions takes time and their political stability and democratic potential are directly proportionate to the length of time during which the country has been developing democracy. The European integration represents, in that regard, a fasting track and Serbia and Montenegro are going fast. The region, however, has put on that track other countries as well. The new methodology has to be appreciated in that context. What seems to be the answer is that Macron is advocating for a faster track, with probably a group rather than the regatta approach.

The lack of an effective accession methodology has produced the idea and need to tighten eventually the conditions for aspiring member states. As an ad hoc procedure, the methodology has been changing according to the need and political situation in the EU itself. The strict conditions for the Western Balkans states, in that context, represent just a culmination of distrust towards new members and need to slow the enlargement. The need for a slower enlargement is also a reflection of what is dominant political thought in the EU: we cannot accept more countries before we change the rules of the game.

The events from 2014, precisely the annexation of Crimea, marked the beginning of a new phase in the international arena, when the relations between the West and Russia plummeted. The EU, already challenged at various geopolitical fronts in its neighbourhood, now had one that took a lot of its political attention away from other matters. The Brexit process added a new and bigger worry. As a result, the accession process, shaped as a bureaucratic procedure that has to be initiated by a political will, suffered when the attention of the EU's and national policymakers of the member states drew away from it, tacitly marking it as a secondary matter.

The EU is constantly changing, so is its surroundings. However, its goals, the ones that underpin the European project, those remain the same. European unity, 
as a foremost economically driven project, declares that it wants the whole European continent in one community. The period of time it takes to accomplish these goals is equally important. The Eastern European ex-communist countries, that are seeing the European integration as a tool for effective state-crafting and implementation of the Western system of values, are proof that time is particularly important. The same goes for the Western Balkan states, where many problems inherited from the dissolution of Yugoslavia are still slowing down the velocity of their European integration. The EU, from the other side, can manage the process and eventually fasten it by means of supporting democratic processes.

Many authors confirm that democracy will be bolstered by the accession to the EU. In fact, in relation to the Eastern European Countries, it is said that:

"Accession will reconfigure political and discursive assets and incentives in ways that help the liberal-democratic and hinder the authoritarian political forces in new Member States. This is perhaps the best thing about the democracy dividend of the EU accession process". ${ }^{16}$

The negotiation process formally has two interlocutors: the candidate country and the European Commission. However, there are many more actors who unofficially influence the candidate country's path towards the accession: social actors within the candidate country, NGOs, but also Member states of the EU with their specific interests. The political momentum, which is expressed in the decision on the opening of new chapters, taken by the European Council - that is by single member states - has a far greater influence on the accession path and can eventually slow it down or bolster it. The continuity of the process is the first element that eventually suffers from political instability. However, it is the continuity that has to be guaranteed. The accession methodology should, therefore, primarily guarantee the stability of the process in time and neutralise negative political influences, which play a major role in the overall enlargement context.

Major part of the negotiations is subject to control and close scrutiny exercised by the Commission. The Commission acts as a "central body for administration and content during the course of negotiations" ${ }^{17}$ It is, however, the Commission that should be empowered more in relation to the management of the process, as the European Council is the one that decides on opening of the chapters, taking the

16 Sadurski, W.; Czarnota, A.; Krygier, M., Spreading Democracy and the Rule of Law?, The impact of the EU enlargement on the Rule of Law, Democracy and Constitutionalism in Post-Communist Legal Orders, Springer, The Netherlands, 2006, p. 49

17 Barnes, I.; Barnes, P., 2010 Enlargement, in: Cini M.; Perez Solorzano Borragan, N. (eds.), European Union Politics, 3rd edn, Oxford, Oxford University Press, p. 418-434 
key element away from the Commission. The fact that the decision is a political one harms the integrity of the accession methodology, and puts the continuity of the process in second place to the political will of (some) member states. Furthermore, as the negotiating process lacks integrity, the enlargement process is open and vulnerable to malign political instrumentalization from third countries.

It seems fair to pose a question of whether the enlargement process should be immune to the historic momentum and therefore avoid being subject to the mercy of geopolicy's mood. The enlargement methodology should be the best guarantor of that immunity and it seems that Macron's deal would not seal it. The enlargement fatigue from one side and the negotiation fatigue from the other are reflections of the same inefficacy that could be fixed strengthening the institutional participation and involvement of candidate countries, the economic aid through access to structural funds and other forms of more substantial connections.

\section{RULE OF LAW AND DEMOCRACY VS. LAW OF POWER AND AUTOCRACY}

The Rule of Law is the ground basis for the development of Democracy. This is particularly important when it comes to the process of Europeanization of the Western Balkan states. In this particular context, it is critical to note that the accession methodology has to guarantee a stable pace of implementation of the Rule of Law principle. The current situation, where the enlargement policy is being put aside, demonstrates that the actual methodology is not effective. This can come as a result of two specific factors, which the accession methodology should have avoided: the EU's ineffectiveness in policy decision making, directly proportional to the heterogeneity and multipolarity of the geopolitical situation in the world, and the rather young age of the Western Balkan democracies. The slowing down of the process of enlargement, due to political events as mentioned above, delays the application of the Rule of Law principle and makes the process ineffective. An ineffective accession methodology, therefore, produces a risk of rise of authoritarianism on the one hand and geopolitical fails for the EU in its immediate neighbourhood, on the other hand.

Macron's proposal for a new methodology starts by announcing a stronger political involvement of the Member States and a phasal introduction of candidate countries to the EU's institutions, accompanied by the right to apply for grants directly to the EU's structural funds. Where the institutionalisation of candidate countries could have a firm impact on democratic development and a rather stabilisation effect, the political involvement of Member States does not seem promising. Macron wants to put the accession talks out of the technocratic process. By 
directing it towards national parliaments and governments, this proposal commits an error. The political involvement could put the same process at the mercy of the political and bureaucratic procedures of single member states. While the first would be beneficial for the Rule of law and democracy, the second aspect would mean itself a constant threat to the continuity of the process.

Meanwhile, the state of play in the Western Balkans countries- "falling in the wide spectrum between consolidated democracies and autocracies"18 was pointed out by many international actors that are monitoring the democratic trends in the region, among which by the EU, in its Communication on a credible enlargement perspective for the region, realised in 2018. In this strategy some major challenges the respective countries are facing, were brought in a rather straightforward way by stating "[...] the countries show clear elements of state capture, including links with organised crime and corruption at all levels of government and administration, as well as a strong entanglement of public and private interests. All this feeds a sentiment of impunity and inequality." 19

Therefore, the political situation and its trends have penetrated into a process that should have been immune to that and have produced a stalemate: the EU is not opening chapters as before to Serbia and Montenegro, and North Macedonia and Albania have been martyred because of the abovementioned negative image the Western Balkans have.

Furthermore, in the academic literature, many prominent authors in this field, namely Keil, Kmezić, Bieber, ${ }^{20}$ Wunsch, Zweers provided plenty of arguments on how the rise of the authoritarian tendencies and widespread state capture hinder effective democratic transformation and prevent functioning rule of law in the case of Western Balkans. ${ }^{21}$

18 Collier, D.; Levitsky, S., Democracy with adjectives: Conceptual innovation in comparative research, World Politics, vol. 49, no. 3, 1997, p. 430-451

19 European Commission, A credible enlargement perspective for an enhanced EU engagement with the Western Balkans, Strasbourg, 6 February 2018, 2018/65/EC, [https://ec.europa.eu/commission/ sites/beta-political/files/communication-credible-enlargement-perspective-western-balkans_en.pdf], accessed on 08. March 2020

20 Kmezić, M.; Bieber, F., The crisis of democracy in the Western Balkans: An autonomy of stabilitocracy and the limits of the EU democracy promotion, Belgrade: Balkans in Europe Policy Advisory Group, 2017, [biepag.eu/publications/the-crisis-of-democracy-in-the-western-balkans-authoritarianism-and-eu-stabilitocracy/], accessed on 08. March 2020

$21 \quad$ Ibid. 
Although there is no great master plan behind the EU integration, ${ }^{22}$ the phenomenon of the rise of new semi-authoritarian regimes also creates suspicion over the level of transformative power of EU integration processes. Marko Kmezić, states that "three decades since the beginning of democratization processes, the Western Balkan countries have built a democratic facade by holding elections", ${ }^{23}$ further implying that something went wrong in the whole process. ${ }^{24}$

The EU and its Member States should not disregard the lessons learned from the past decade, which transcend deeper messages, among which that a continuation of the status quo will not lead to more democratisation, it will not stop corruption, or create more pro-European governments in the region. To the opposite, adhering to the status quo - the so-called "pax-Junckeriana" ${ }^{25}$, could only lead to further consolidation of competitive autocratic regimes in the Western Balkans and to a decline in popular support towards Europeanization in its broadest sense. Overall, the paradox of moving closer to the EU but further away from democracy and the rule of law, and its negative effects should be seriously taken by both sides, the EU and respective states from the region, in their calculation of the pragmatic goals and priorities in the upcoming years, irrespective of how far they are looking at while acting.

It seems fair to state, however, that a political involvement of Member States puts the accession talks into internal political debate of those States rather than to the geopolitical arena, as the candidate countries would like. The political momentum of the negotiation process there has the potential of working against the interests of the candidate countries. Considering that the length of time for a stronger democratic institution is considerably longer than what is needed for a fast integration into the EU, the enlargement methodology has to work to better implement the Rule of Law principle. Therefore, it leads us to conclude that some elements of Macron's proposal would work for a swift enlargement and therefore a boost to democratic development of the candidate states.

22 Borzel, T. A., Building Member States: How the EU promotes political change in its New Members, Accession Candidates, and Eastern Neighbours, Geopolitics, History, and International Relations, vol. 8, no. 1, 2016, p. 76-112, [www.jstor.org/stable/26806075], accessed on 19. March 2020

23 Kmezić, M., Rule of law and democracy in the Western Balkans: addressing the gap between policies and practice, Southeast European and Black Sea studies, 2020, p. 1

24 Zweers, W., Between Effective Engagement and Damaging Politicisation: Prospects for a Credible EU Enlargement Policy to the Western Balkans, Clingendael Institute, 2019

25 Srđan Cvijić is also member of the Balkans in Europe Policy Advisory Group (BiEPAG), this speech was delivered during the conference "The Western Balkans in the European Union: Enlargement to what, accession to what?" that took part on $05^{\text {th }}$ April 2017 


\section{THE FRENCH PROPOSAL'S (GEO)POLITICAL IMPLICATIONS}

The EU faces rift over enlargement policy after French "non" during the October 2019 summit. Due to that reason the EU polity is currently going through an intense period of contestation and challenge, and in order to distance itself from the French "non", the EU Parliament adopted a resolution on 24th October 2019, by which it expressed regret and deep disappointment over the EU's failure to agree on opening negotiation talks with North Macedonia and Albania. ${ }^{26}$ This case demonstrates that the enlargement has shifted, in its political dimension, from the geopolitical arena to the domestic one, as indicated above. The Prespa agreement and reforms that Albania has done should candidate them at least for the opening.

The impasse triggered by the so-called French veto, besides having a negative impact on the credibility of the EU accession policy, it could also reflect negatively on the overall EU Common Foreign and Security Policy, as well as on the EU ability to speak with one voice and act efficiently in its nearer neighbourhood, as well as to become "an active player, and architect of tomorrow's world". ${ }^{27}$ In other words, inward-oriented EU policies and further isolationism could substantially damage the EU's position, and hamper its ability to shape its neighbourhood, while leaving the door open to aspirations of some other global political players.

The protest that came from the EU itself indicated that the enlargement methodology was not within its range of competence, but that individual member States (politicians?) are calling the shots. Different aspects of the Non paper $^{28}$ have been discussed recently, reflecting deeply divided opinions on Macron's proposal within EU circles and wider.

On the one hand, the Non paper is described as an attempt by Paris to justify its prior position, that according to some authors has delivered "a heavy if not mortal blow to the EU's credibility in its nearest neighbourhood". ${ }^{29}$ This view suggests that the mentioned French position has increased doubt among Western Balkan countries on their future EU prospects, and, in a way, pulled the drag on EU en-

26 European Parliament resolution of 24 October 2019 on opening accession negotiations with North Macedonia and Albania, OJ, 24 October 2019, 2019/2883 RSP, [https://www.europarl.europa.eu/ doceo/document/TA-9-2019-0050_EN.html], accessed on 19. March 2020

27 Annual State of the EU address by President Juncker at the European Parliament, State of the Union 2018, The hour of the European Sovereignty, Authorised version of the State of the Union Address 2018, [https://ec.europa.eu/commission/sites/beta-political/files/soteu2018-speech_en_0.pdf], accessed on 19. March 2020

28 Ibid.

29 Fouéré, E., Macron's non to EU enlargement, 22 October 2019, [https://www.ceps.eu/macrons-non-toeu-enlargement/], accessed on 10. January 2020 
largement policy. ${ }^{30}$ In addition, it is stated that it seriously undermined some of the core principles and values, upon which the EU has been created, such as the principle of legal certainty - that in a way predetermines a moment when a country "deserves a certain dose of appreciation" of its efforts invested in the process of the EU accession negotiations. All of this as proof that the current accession methodology is not an autonomous process, but rather a technocratic procedure that is in hands of single member states, given the right to veto.

Some more optimistic views suggest that outlined changes in the negotiation procedure with the Western Balkan countries could actually allow aspiring countries to efficiently adapt to the EU rules before they enter the bloc's institutions. In the same tone, these interpretations support the thesis that Macron's Non paper reflects "unequivocal support" for the EU membership drives of the countries from the Western Balkans under the condition they are able to overcome some major challenges facing nowadays that require "the profound political, economic and social transformations [...] that continue to be too slow and the concrete benefits for citizens in candidate countries remain insufficient". ${ }^{31}$

\section{COMMISSION'S NEW METHODOLOGY, BACKGROUND}

In February 2020, the European Commission published a new enlargement strategy for the Western Balkans. The main purpose of the "new enlargement methodology" is to help the EU to overcome the impasse triggered by the so-called French veto. This document promises "a new reinforced negotiation process," and its delivery to be supported by the EU in different aspects, while also putting a stronger emphasis on the involvement of the sole Candidate states' structures in the overall process (making them acquire feeling that they have ownership over the process). Enlargement Commissioner Olivér Várhelyi, declared that the revised negotiation rules "are supposed to inject credibility, predictability, dynamism and a political steer into the increasingly moribund process. This is called a geostrategic investment". ${ }^{32}$ Consequently, many Western Balkan officials welcomed the plan by expressing the hope that this revitalized approach will result in a win-win situation for all actors involved.

30 Herszenhorn, M. D.; Momtaz, R., France outlines proposal to overhaul EU accession process, 18 November 2019, [https://www.politico.eu/article/france-outlines-proposal-to-overhaul-eu-accession-process/], accessed on 20. January 2020

31 Non-Paper, Reforming the European Union accession process, November 2019, [https://www.politico.eu/wp-content/uploads/2019/11/Enlargement-nonpaper.pdf], accessed on 10. January 2020

32 Makszimov, V., Commission tries to breathe new life into EU enlargement, 6 February 2020, [https:// www.euractiv.com/section/all/news/commission-tries-to-breathe-new-life-into-eu-enlargement/], accessed on 03. March 2020 
The pledge of greater importance being afforded to greater scrutiny over the reform processes is regarded to be good news for all actors wishing progress in the region that witnessed many challenges, corruption scandals, etc. in the past decade. In light of recent events "augmenting the trust" ${ }^{33}$ in the sole EU integration process, which is capable of inducing genuine reforms within the countries involved, has become extremely important. Nevertheless, it remains to be seen what would be the practical results of such a strategy, and whether the European Union will devote greater attention to the area of the so-called "fundamentals", and whether all this together will provide an adequate impetus for the Western Balkans in the period ahead. Solutions that could lead to this desirable outcome are a more transparent, more credible approach accompanied by the merit-based awards, founded on the individual countries' accession efforts, which all together could make a difference.

\section{THE EU METHODOLOGY, "STICK AND CARROT” APPROACH}

The new EU Commission negotiations methodology provoked many different sentiments since its public revelation. These sentiments range from excitement about the fact that the EU finally put the topics related to Western Balkans accession on the list of its priorities, to some sceptic notions that the new methodology maybe overhauls the French veto, but that it does not convincingly address the real "elephant in the room". In other words, the new methodology highlights the geopolitical importance of the Western Balkans for the EU declaring that "[...] meritbased prospect of full EU membership for the Western Balkans is in the Union's very own political, security and economic interest. In times of increasing global challenges and divisions, it remains more than ever a geostrategic investment in a stable, strong and united Europe". On the other hand, it remains unclear to what extent this new methodology would be efficient, in terms of not only dealing with resentment caused by French "non", but also in light of the basic purpose of the strategy that should be embodied more "merit-based", "transparent, credible", and in general better approach towards the Western Balkans.

This new strategy, that the EU Commission advocates for, is following very the same logic of the previous enlargements containing the elements of stick and carrot policy. The major difference in the overall logic applied, seems to be the degree of severity of the stick, and the rewarding level of the carrot.

33 Verhaegen, S. et al., The Effect of Political Trust and Trust in European Citizens on European Identity, European Political Science Review, vol. 9, no. 2, 2017, p. 161-181., [doi:10.1017/S1755773915000314], accessed on 25. March 2020 
Reflecting on the "stick side" of the strategy, the so-called reversibility of the negotiation process is not an innovative concept mentioned in the new Strategy. Calling upon the previous terminology used by the European Commission, it is a new term for the "clause of balance", which main goal was ensuring balance in the progress of negotiations across Chapters. According to this rule, if progress under the Chapters "judiciary and fundamental rights" and "justice, freedom and security", was significantly lagging behind, the Commission was allowed to recommend various measures until the imbalance is adequately addressed. These measures include withholding opening or closing negotiation chapters, reopening provisionally closed chapters, cutting down the EU funding, suspension or withdrawing benefits of closer integration, etc. The Council is a body entitled to decide upon introducing or lifting such measures proposed by the Commission, acting by a qualified majority voting rule. The logic present in the New methodology is pretty much the same. ${ }^{34}$

Nevertheless, per se, it does not mean much, but something that could really make a difference in this regard would be a diligent approach towards fulfilling the respective criteria in these critical areas, shown by all actors involved in the accession negotiation processes. Therefore, the practice of introducing reforms of declaratory nature, without proper implementation of rules, that has recently allowed countries to compete for the status of the "regional leader" in EU integrations, should be dismissed once for all. This sort of EU integration race that has been created so far, is not something that could be described as a healthy competition leading to growth or prosperity, as it has not been based on genuine respect of values and ideas upon which the sole process is based. Therefore, the narratives such as the "leader in the region" does not mean much in the current state of play, without emphasis put on substantial reforms conducted for the benefit of all countries involved and wellbeing of their citizens.

This endeavour will require stronger mechanisms for the enforcement of the rules and standards belonging to the EU acquis. Dabrowski, and other authors suggest that among these mechanisms should be "a regular Commission's assessment of member states' records in the area of fundamental rights and the rule of law, more active use of infringement procedure in case of failure to implement EU law, strengthening competences of the Court of Justice of the EU". ${ }^{35}$

34 Communication from the Commission to the EU Parliament, the Council, the European Economic and Social Committee and the Committee of the Regions, Enhancing the accession process - A credible EU perspective for the Western Balkans, OJ, 5 February 2020, 2020/57/EC, [https://ec.europa. eu/neighbourhood-enlargement/sites/near/files/enlargement-methodology_en.pdf], accessed on 28. March 2020

35 Dabrowski, M., Can the EU overcome its enlargement impasse?, Bruegel, [https://www.bruegel. org/2020/02/can-the-european-union-overcome-its-enlargement-impasse/], accessed on 25. March 
Moreover, a stronger political steer is envisaged to allow high representatives of the (potential) candidate states to be involved more systematically in monitoring and reviewing the process. This step could be also interpreted as beneficial in a way it would allow incumbent elites as well as the rest of society in the region to acquire a feeling they have greater ownership over the process.

The "carrot" aspect of the strategy implies prospects of the clearer and tangible incentives of the imminent interest to citizens such as increased funding and investments "through a performance-based and reform-oriented Instrument for Preaccession support and closer cooperation with IFIs to leverage support", as well as "accelerated integration and "phasing-in" to individual EU policies, the EU market and EU programmes", as well as some other things such as greater clarity on what the EU expects from the (potential) candidate countries. ${ }^{36}$

The so-called "phasing in" was accompanied with a pretty vague explanation, while it also did not provide an answer over the concerns of whether it will be more comprehensive than integration provisions of Stabilization and Association Agreements. Furthermore, many concerns were raised over the new Multinational Financial Framework and its ability to allocate more funds for the pre-accession aid to the EU candidates.

While negative incentives in the process of the EU integrations were seem to be winning the battle recently, the EU should bear in mind that the critical issue in the overall process is keeping the Enlargement process affordable to the (potential) candidate states, which means that in the upcoming period the EU needs to demonstrate that it is able to deliver on its historical promise given to the Western Balkans at the Thessaloniki summit.

\section{PROS AND CONS TO THE EU COMMISION'S METHODOLOGY}

The opinions on the New EU Commission Strategy are pretty diverse.

In light of positive aspects of the new methodology, it is particularly important to mention those related to the stronger political steer over the process by both the $\mathrm{EU}$ as well as by the incumbent elites from the aspiring countries. First, by en-

\section{0}

36 Communication from the Commission to the EU Parliament, the Council, the European Economic and Social Committee and the Committee of the Regions, Enhancing the accession process - A credible EU perspective for the Western Balkans, OJ, 5 February 2020, 2020/57/EC, [https://ec.europa. eu/neighbourhood-enlargement/sites/near/files/enlargement-methodology_en.pdf], accessed on 28. March 2020 
couraging all actors from the EU circles to speak with one voice, the Commission seeks to push the EU as a whole to reaffirm loyalty and its genuine commitment to enlargement. Furthermore, enhancing loyalty between the EU Member States is of the crucial value as it is "at a comparatively high level of abstraction aimed to protect the Union's ability to act effectively on the international plane". ${ }^{37}$ Second, the Commission undoubtedly wants to give greater public legitimacy to the cause, as the new proposal envisages innovative means to instigate and check the devotion of the region's authorities to the EU membership goal, among which are informed national-wide debates.

The new Commission proposal also embraces the so-called grouping of negotiations chapters into six thematic chapters. The Commission names few reasons making this new approach plausible. Firstly, it states that it will allow "a stronger focus on core sectors in the political dialogue". Secondly, it will help identify the most important and urgent reforms per sector. On the other hand, many concerns have been raised so far, over the Commission belief - that this approach could even speed up the overall negotiation process, as it could happen only if some secondary and less important issues would not hold the entire negotiation cluster. Currently, there are no guarantees for that, which makes this Commission's "belief" fragile, and potentially brings the rest into an uncertain position.

Looking from the perspective of the long-term benefits that this new methodology is offering to the countries concerned, it can be said that these benefits directly stem from the more intrusive scrutiny over the reform in the areas of rule of law, fight against organized crime and tackling corruption ${ }^{38}$ in the Western Balkan countries. In other words, these reforms should be regarded as essential, due to the general atmosphere that improvements in these critical areas are precondition to any sort of meaningful progress of the countries belonging to the region - leading to the well-being of its citizens.

On the other hand, some authors who are criticising the methodology such as Bodo Weber, argue that the Commission's proposal does not address the fundamental problem of the EU enlargement policy, which is not the methodology, but it is related to the deeper dilemma of "what kind of the EU we actually want"? By saying this, he is actually opening a Pandora box of proposals for reforming the EU that the EU officials were not able to agree upon by date.

37 Eckes, C., Disciplining Member States: EU Loyalty in External Relations, Cambridge Yearbook of European Legal Studies, 2020, p. 1-21

38 Mungiu-Pippidi, A. et al., "A House of Cards?: Building the Rule of Law in the Balkans" in The Western Balkans and the EU: 'The Hour of Europe', in: Rupnik, J. (ed.), European Union Institute for Security Studies (EUISS), 2011, p. 155 
Reforms related to the EU negotiating strategy, and to the general EU approach towards the Western Balkans, are indispensable for the benefit of the region, as they could bring end to the practices such as perpetuation of informal power structures, state capture and patronage that continue to thwart the region's democratic consolidation. Above and beyond, regional challenges are coupled with the necessity for internal consolidation of the EU - that should not happen at the expense of the countries that are waiting in line to join the EU. The EU internal consolidation could happen in parallel with continuing the negotiation processes with Western Balkan countries, therefore not endangering important aspects of the EU project, such as the capacity and credibility of its foreign policy.

Nevertheless, it remains to be seen whether the New strategy addresses convincingly the elephant in the room embedded in "deepening vs. enlargement dilemma", as well as the so-called sense of betrayal felt by Western Balkan citizens and governments, and a certain "loss of faith" in the European project in the wake of France's "veto" of accession talks for two Western Balkan states, etc. When entering into conclusions we need to bear in mind that idealistic visions of a sui generis community such as the EU, are beneficial to the extent they serve to remind us about the desired direction in which the EU should move, but on the other hand, reality we are facing is a slightly different and most of the time challenging. It often tests the level of solidarity and democracy that the EU itself and its members project between themselves and beyond. This reality check often calls into question idealistic visions, which is not a reason to abandon the idea of the EU. Conversely, the lessons learned should be a way to advance a community such as the EU, and this is precisely the goal to which all EU members, as well as the (potential) candidates, wishing peace and progress of the European continent, should strive to contribute.

\section{CONCLUSION}

In the previous decades the EU has been facing many challenges and many of the stone ideas constituting the essence of this peace project have been placed on some historical tests. However, the challenges on the road have not managed to discredit its direction of travel, and European integration project has proven to be exceptionally resilient.

This resilience also proves that the accession methodology is much more than a bureaucratic process, that the EU's core principles are much more than judicial norms. They respond to the most basic question of all: what do we stand for? The Western Balkan states came across a deep transformation, from a communist utopia to a market-based economy reality. The implementation of norms and 
principles is the substantial address of the accession process, but it has to deal with the fact that the build-up of institutions, especially strong ones, takes time. Democracy needs time and stability to grow.

The idea of a new methodology comes from a genuine need and desire to change what has demonstrated not to be much effective: the Enlargement policy, as a sharp Foreign policy tool, has been blunted by geopolitics, and lack of coherence. The processes happening within the region or within the specific candidate state, are sometimes also coupled with anxieties related to the EU's own internal economic, political and institutional crises. This allows for scenarios, such as the recent one where Albania and North Macedonia were blocked on their path towards opening the negotiation process, that seriously calls into question the assumption of the "merit based" nature of the EU negotiation process.

As it has been indicated throughout the paper, the actual direction in which the European integration is going to move will depend on many factors. Here we should not neglect the influence of the inward-oriented policies, as well as presence of a broader (geo)political bargaining strategies among EU member states with different tendencies, goals, perceptions of their own raison d'etat. It's precisely the enlargement methodology that should be the best guarantor of the immunity of the process from the inward-oriented policies or (geo)political calculations. The enlargement fatigue from one side, and the negotiation fatigue from the other, are a reflection of the same inefficacy that could be fixed by improving credibility of the overall EU approach towards the Western Balkans followed by some concrete steps such as strengthening the institutional participation and by providing them with support through access to structural funds, etc.

In light of recent events, a credible enlargement conditionality, based on the principles such as transparency, certainty, graduality, individuality, being at the heart of the EU Accession process, seems to be needed more than ever. Moreover, looking from the lenses of the Western Balkans the new accession methodology is expected to prove that the negotiation process is trustable and a strong impenetrable path, immune to (geo)political turmoils or political moods of member states. In order to achieve these goals, it is clear that the actual structure needs changes. With Non paper Macron is pointing at the right direction. However, it is only a basis, a solid ground for more ambitious ideas. One of these would be shifting decision-making power from the national capitals to the supranational level/EU institutions when it comes to decisive moments, in order to prevent aggressive political involvement of certain member states, leading to the scenario we have recently witnessed. 
The Enlargement itself, seen as a change within the EU's ranks, has already demonstrated capacity to influence the EU's foreign policy, as some authors say. It gave greater salience to institutional arrangements in the area of human rights, development policies and the broadening nature of security policies". ${ }^{39}$ Therefore, the enlargement is a tool for the enhancement of EU's policies as much as it is a tool for the transformation of candidate countries.

Another scenario, implying further distancing or leaving behind the Western Balkans that geographically belong to the EU, and which historical as well as cultural heritage is deeply interplexed with the heritage of the European Union, would equal to the failure of the European project meant to promote peace, stability and prosperity. It could also open doors to some other major forces having aspirations towards the Western Balkans.

Therefore, in order to secure its sphere of influence, the EU should collectively strengthen its efforts allowing its closest neighbours to join the Union both economically and politically. A stable and economically growing Western Balkans anchored within a stronger European Union is a win-win scenario for all actors involved.

On their part towards joining the ever-closer union, the Western Balkan countries are still left with some of the crucial tasks to do. The new methodology should, therefore, once for all dismantle "tick-the-boxes", "pay lip service" or similar strategies, as they are creating illusions potentially disruptive for the pervasive and transformative process such as the EU accession negotiation process. This novel approach should finally breathe the fresh air into the overall process. While waiting to see how the new system will work in practice, both the EU and the Western Balkans should be prepared to work hard while conducting the mission that will shape the lives of many generations living on the European continent in years to come. This isn't the moment to slow down, but rather to speed up, and this idea will transform itself into concrete political moves, such as the one Macron has made.

\section{REFERENCES}

\section{BOOKS AND ARTICLES}

1. Barnes, I.; Barnes, P., 2010 Enlargement, in: Cini M.; Perez Solorzano Borragan, N. (eds.), European Union Politics, 3rd edn, Oxford, Oxford University Press, p. 418-434

39 Hill, Christofer; Smith, Michael; Vanhoonacker, Sophie, International relations and the European Union, Oxford University Press, 2017, p. 118 
2. Collier, D.; Levitsky, S., Democracy with adjectives: Conceptual innovation in comparative research, World Politics, vol. 49, no. 3, 1997, p. 430-451

3. Cvijić, S., No Open Society - No Resilience, in: Lange S. et al. (eds.); Resilience in the Western Balkans, European Union Institute for Security Studies (EUISS), 2017, p. 71-74

4. Donika, E.; Nechev, Z.; Stakić, I., Game-Changers for the Region, in: Čeperković, M.; Gaub, F. (eds.), Balkan Futures: Three Scenarios for 2015, European Union Institute for Security Studies (EUISS), 2018, p. 19-28

5. Eckes, C., Disciplining Member States: EU Loyalty in External Relations, Cambridge Yearbook of European Legal Studies, 2020, p. 1-21

6. Eriksen, M., Europeanization of the Balkans within an Identity-based Framework, Politeja, no. 37, 2015, p. 193-208

7. Haas, B. E., The Uniting of Europe, Stanford University Press, Stanford, 1958, p. 139-140

8. Hill, C.; Smith, M.; Vanhoonacker, S., International relations and the European Union, Oxford University Press, 2017, p. 54

9. Keil, S., The Business of State Capture and the Rise of Authoritarianism in Kosovo, Macedonia, Montenegro and Serbia, Southeastern Europe, vol. 42, no. 1, 2018, p. 59-82

10. Kmezić, M., Rule of law and democracy in the Western Balkans: addressing the gap between policies and practice, Southeast European and Black Sea studies, 2020, p. 1

11. Levitsky, S.; Way, A. L., Competitive authoritarianism, Hybrid regimes after the cold war, Cambridge University Press, Cambridge, 2010, p. 365-371

12. Mungiu-Pippidi, A., et al., "A House of Cards?: Building the Rule of Law in the Balkans" in The Western Balkans and the EU: 'The Hour of Europe', Rupnik, J. (ed.), European Union Institute for Security Studies (EUISS), 2011, p. 155

13. Sadurski, W.; Czarnota, A.; Krygier,M., Spreading Democracy and the Rule of Law?, The impact of the EU enlargement on the Rule of Law, Democracy and Constitutionalism in PostCommunist Legal Orders, Springer, The Netherlands, 2006, p. 49

14. Sjursen, H.; Smith, E. K., Justifying EU Foreign Policy, the logics underpinning enlargement, in: Tonra, B.; Christiansen, T. (eds.), Rethinking European Union Foreign Policy (Europe in Change), Manchester University Press, Manchester, 2004, p. 134

15. Triantaphyllou, D. et al., The Balkans between Stabilisation and Membership, in Partners and Neighbours: a CFSP for a Wider Europe, European Union Institute for Security Studies (EUISS), 2003, p. 69-71

16. Zweers, W., Between Effective Engagement and Damaging Politicisation: Prospects for a Credible EU Enlargement Policy to the Western Balkans, Clingendael Institute, 2019

\section{EU LAW}

1. Treaty on functioning of the European Union (Consolidated version 2016) Art. 49, [2016] OJ C 202/43

2. Treaty on European Union (Consolidated version 2016), Arts. 8-8e, Citizenship of the Union, [2016] OJ C202/43 
3. Communication from the Commission to the EU Parliament, the Council, the European Economic and Social Committee and the Committee of the Regions, Enhancing the accession process - A credible EU perspective for the Western Balkans, OJ, 5 February 2020, 2020/57/EC

4. European Commission, Communication from the Commission to the European Parliament, the Council, the European Economic and Social Committee and the Committee of the Regions, 2019 Communication on EU Enlargement Policy, Brussels, OJ, 29 May 2019, 2019/260/EC

5. Commission Staff Working Document Serbia 2019, Report Accompanying the document Communication from the Commission to the European Parliament, the Council, the European Economic and Social Committee and the Committee of the Regions 2019 Communication on EU Enlargement Policy, OJ, 29 May 2019, 2019/260/EC

6. European Commission, A credible enlargement perspective for an enhanced EU engagement with the Western Balkans, Strasbourg, OJ, 6 February 2018, 2018/65/EC

7. European Parliament resolution of 24 October 2019 on opening accession negotiations with North Macedonia and Albania, OJ, 24 October 2019, 2019/2883 RSP

8. Non-Paper, Reforming the European Union accession process, November 2019, [https:// www.politico.eu/wp-content/uploads/2019/11/Enlargement-nonpaper.pdf], accessed on 10. January 2020

\section{WEBSITE REFERENCES}

1. Annual State of the EU address by President Juncker at the European Parliament, State of the Union 2018, The hour of the European Sovereignty, Authorised version of the State of the Union Address 2018, [https://ec.europa.eu/commission/sites/beta-political/files/ soteu2018-speech_en_0.pdf], accessed on 19. March 2020

2. Appicciafuoco, L., The Promotion of the Rule of Law in the Western Balkans: The European Union's Role, German Law Journal, vol. 11, no. 7-8, 2010, p. 761, [doi:10.1017/ S2071832200018824], accessed on 20. March 2020

3. Borzel, T. A., Building Member States: How the EU promotes political change in its New Members, Accession Candidates, and Eastern Neighbours, Geopolitics, History, and International Relations, vol. 8, no. 1, 2016, p. 76-112, [www.jstor.org/stable/26806075], accessed on 19. March 2020

4. Cardona F., Integrating national administrations into the European administrative space, SIGMA Conference on Public Administration Reform and European Integration, March 2009, p. 26-27 [http://www.sigmaweb.org/publicationsdocuments/42747690.pdf], accessed on 23. February 2020

5. Dabrowski, M., Can the EU overcome its enlargement impasse?, Bruegel, [https://www.bruegel.org/2020/02/can-the-european-union-overcome-its-enlargement-impasse/], accessed on 25. March 2020

6. Erwan, F., Macron's “non” to EU enlargement, 22 October 2019, [https://www.ceps.eu/macrons-non-to-eu-enlargement/], accessed on 18. February 2020

7. Europe's population, [https://www.worldometers.info/world-population/europe-population/], accessed on 24. February 2020 
8. Herszenhorn, M. D.; Momtaz, R., France outlines proposal to overhaul EU accession process, 18 November 2019, [https://www.politico.eu/article/france-outlines-proposal-to-overhauleu-accession-process/], accessed 20. January 2020

9. Kmezić, M.; Bieber, F., The crisis of democracy in the Western Balkans: An autonomy of stabilitocracy and the limits of the EU democracy promotion, Belgrade: Balkans in Europe Policy Advisory Group, 2017, [biepag.eu/publications/the-crisis-of-democracy-in-the-westernbalkans-authoritarianism-and-eu-stabilitocracy/], accessed on 08. March 2020

10. Kühn, Z., The Application of European Law in the New Member States: Several (Early) Predictions, German Law Journal, vol. 6, no. 3, 2005, p. 563-582., [doi:10.1017/ S207183220001381X], accessed on 02. March 2020

11. Makszimov, V., Commission tries to breathe new life into EU enlargement, 6 February 2020, [https://www.euractiv.com/section/all/news/commission-tries-to-breathe-new-life-into-euenlargement/], accessed on 03. March 2020

12. Verhaegen, S. et al., The Effect of Political Trust and Trust in European Citizens on European Identity, European Political Science Review, vol. 9, no. 2, 2017, p. 161-181., [doi:10.1017/ S1755773915000314], accessed on 25. March 2020 